\title{
The Effect of Parenting Patterns on Pre School Age Children Development in South Central Timor
}

Senny R. Taimenas*, Stefanus P. Manongga, Frans Umbu Datta, Herianus J.D. Lalel, Christina Olly Lada Public Health Sciences Faculty Students, Post-Graduate Program, Nusa Cendana University, Kupang-85001, East Nusa Tenggara, Indonesia

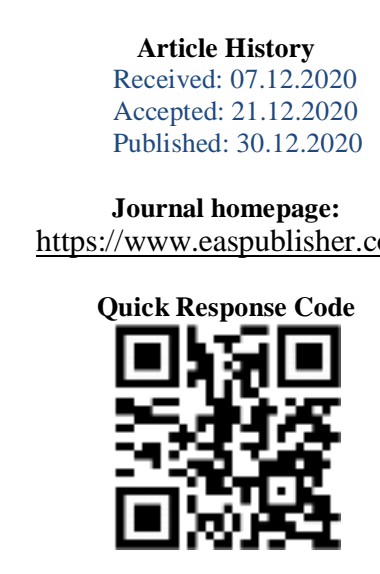

Abstract: Parenting patterns are the care that is given by the mother or other caregivers in the form of attitudes and behaviors in terms of their closeness to children, feeding, caring for cleanliness, giving love and so on. Good care is very important to ensure optimal growth and development of children, therefore, poor care can cause children to have less nutritional status. This type of research is analytic observational usingdesign cross sectional. The sample in this study was parents and pre-school children aged 4-5 years, so that the number of samples in each region was 73 parents and 73 preschool children aged 4-5 years. Sampling was done by using cluster sampling method, purposive sampling and stratified sampling. The results of thetest chi square showed that the $p$-value was smaller than $\alpha 0.05$, so the analysis showed that there was a significant effect of feeding practices on children's development. The results of thetest chi square showed that the p-value was 0.000 smaller than $\alpha 0.05$, so the analysis showed that there was a significant effect of hygiene and health practices on children's development. The results of thetest chi square showed a $p$-value of 0.000 smaller $\alpha 0.05$, so the results of the analysis showed that there was a significant effect of the practice of hygienic affection on child development. The results of thetest chi square showed a $p$-value of 0.000 smaller $\alpha 0.05$, so the results of the analysis showed a significant effect of stimulation practice on child development.

Keywords: Parenting, pre-school age development, stimulation, hiegene.

Copyright (C) 2020 The Author(s): This is an open-access article distributed under the terms of the Creative Commons Attribution 4.0 International License (CC BY-NC 4.0) which permits unrestricted use, distribution, and reproduction in any medium for non-commercial use provided the original author and source are credited.

\section{INTRODUCTION}

Children are individuals who are experiencing a very rapid process of growth and development. It is even said to be a developmental leap. That's why at an early age it is said to be the Golden Age, which is a very valuable age compared to the next age. Therefore, disruption of growth and development of early childhood will have an impact on future growth and development [1].

Development is the increase in abilities (skills) in a more complex structure and function in a regular and predictable and predictable pattern, as a result of the maturation process. Child development is related to qualitative changes which include several dimensions of child development, namely fine motor development, gross motor skills, speech and language, independence and socialization [2].

Developmental disorders in children include impaired development of gross motion, fine movements, socialization and independence as well as speech and language development, which of these four sectors if a child experiences disturbances or delays in development it will affect the subsequent child's development. Children's intellectual development can be seen from the symbolic or abstract abilities such as speaking and language, while emotional development can be seen from the children's social behavior and independence with their environment. If the child experiences delays in the speech and language sector, it will have difficulty interacting with the surrounding environment, while for social development the child will experience difficulties in socializing with friends and other people around him [3].

According to a report from the Ministry of Health of the Republic of Indonesia in Lombonaung et al. [4] the coverage of toddler health services in early detection of toddler growth and development is $78.11 \%$. The number of children under five who experience growth and development disorders in Indonesia is $45.7 \%$. The child development index in Riskesdas is seen from the aspects of literacy, physical, social emotional, and learning. Based on the results of the 2018 Riskesdas, it was found that the index of child development in Indonesia was $88.3 \%$ and in NTT Province it was around $80 \%$.

All factors that influence child development are strengthened by research studies conducted by 
several researchers. Research conducted by Fitri [5] shows that there is a relationship between maternal age and the ability to stimulate gross motor development of children aged 0-12 months in Bukit Meusara Village, Jantho City. Research by Waqidil [6] shows that there is a relationship between the level of mother's education and child development and based on research conducted by Ering [5], there is a strong relationship between the status of working mothers and children's social abilities.

Timor Tengah Selatan Regency is a district where the number of children suffering from stunting in 2018 reached $52.76 \%$, this means that South Central Timor Regency is one of the highest districts in East Nusa Tenggara (NTT) and Number 2 National. Stunting in toddlers is a nutritional problem that can hinder children's development, with negative impacts that can affect life in the future, such as intellectual decline, decreased productivity, susceptibility to infectious diseases to poverty and the risk of giving birth to babies with LBW [7, 4]. Many factors are associated with the incidence of inadequate food stunting and disease as a direct cause, in addition to inappropriate feeding practices, recurrent illnesses and infections, poor hygiene and parenting behaviors [7].

Parenting patterns are care that is given by mothers or other caregivers in the form of attitudes and behaviors in terms of closeness to children, feeding, caring for cleanliness, giving love and so on [8]. Good care is very important to ensure optimal growth and development of children, therefore, poor care can cause children to have less nutritional status [5].

\section{Methodology}

This research is an analytic observational study using adesign cross sectional. The sample in this study was parents and pre-school children aged 4-5 years, so that the number of samples in each region was 73 parents and 73 preschool children aged 4-5 years. This research will be conducted in South Central Timor Regency. The research was carried out in June - July 2020. Since the research letter was issued by the University of Nusa Cendana.

The data analysis technique used in this study is bivariate analysis using chi Squere which is used on nominal and ordinal scale data to determine whether there is a relationship between 2 independent variables and the dependent variable.

\section{RESULTS}

Table-1: Distribution of Respondents According to Parenting (feeding practices, hygiene and health practice, practice and practice compassion stimulation)

\begin{tabular}{|l|c|c|c|}
\hline \multicolumn{1}{|c|}{ Variable } & Criteria & $\mathbf{N}$ & $\mathbf{\%}$ \\
\hline feeding Practices & Less & 88 & 40.2 \\
\cline { 2 - 4 } & Good & 131 & 59.8 \\
\cline { 2 - 4 } & Total & 219 & 100 \\
\hline \multirow{3}{*}{$\begin{array}{l}\text { The practice of hygiene } \\
\text { and health }\end{array}$} & Less & 92 & 40.2 \\
\cline { 2 - 4 } & both & 127 & 58.0 \\
\cline { 2 - 4 } & Total & 219 & 100 \\
\hline \multirow{3}{*}{$\begin{array}{l}\text { The practice of } \\
\text { compassion }\end{array}$} & Less & 107 & 48.9 \\
\cline { 2 - 4 } & well & 112 & 51.1 \\
\cline { 2 - 4 } & Total & 219 & 100 \\
\hline stimulation Practice & Less & 70 & 46.1 \\
\cline { 2 - 4 } & good & 149 & 53.9 \\
\cline { 2 - 4 } & Total & 219 & 100 \\
\hline
\end{tabular}

Table-2: Effect of parenting to the child's development.

\begin{tabular}{|c|c|c|c|c|c|c|c|c|c|}
\hline \multirow{3}{*}{ Variable } & \multirow[t]{3}{*}{ Criteria } & \multicolumn{6}{|c|}{ Child Development } & \multirow[t]{3}{*}{ P-Value } & \multirow[t]{3}{*}{$\mathbf{R P}$} \\
\hline & & \multicolumn{2}{|c|}{$\begin{array}{c}\text { Available } \\
\text { delay }\end{array}$} & \multicolumn{2}{|c|}{ None delay } & \multicolumn{2}{|c|}{ Total } & & \\
\hline & & $\mathbf{N}$ & $\%$ & $\mathbf{N}$ & $\%$ & $\mathbf{N}$ & $\%$ & & \\
\hline \multirow{3}{*}{$\begin{array}{l}\text { Practice } \\
\text { Giving food }\end{array}$} & Less & 51 & 23.3 & 37 & 16.9 & 88 & 40.2 & \multirow[t]{3}{*}{0.001} & \multirow[t]{3}{*}{2,634} \\
\hline & Good & 45 & 20.5 & 86 & 39.3 & 131 & 59.8 & & \\
\hline & Total & 96 & 43.8 & 123 & 56.2 & 219 & 100 & & \\
\hline \multirow{3}{*}{$\begin{array}{l}\text { Practice } \\
\text { hiegene and health }\end{array}$} & Poor & 75 & 34.2 & 17 & 7.8 & 92 & 42 & \multirow[t]{3}{*}{0.000} & \multirow[t]{3}{*}{22,269} \\
\hline & Good & 21 & 9.6 & 106 & 48.4 & 127 & 58 & & \\
\hline & Total & 96 & 43.8 & 123 & 56.2 & 219 & 100 & & \\
\hline \multirow{3}{*}{$\begin{array}{l}\text { Practice } \\
\text { love } \\
\text { dear }\end{array}$} & Less & 22.960 & 37.4 & 25 & 11.5 & 107 & 48.9 & \multirow[t]{3}{*}{0.000} & \multirow[t]{3}{*}{22,960} \\
\hline & Good & 14 & 6.4 & 98 & 44.7 & 112 & 51.1 & & \\
\hline & Total & 96 & 43.8 & 123 & 56.2 & 219 & 100 & & \\
\hline \multirow{3}{*}{$\begin{array}{l}\text { Practice } \\
\text { Stimulation }\end{array}$} & Less & 9.074 & 18.7 & 29 & 13.3 & 70 & 32 & \multirow[t]{3}{*}{0.003} & \multirow[t]{3}{*}{9,074} \\
\hline & Good & 55 & 25.1 & 94 & 42.9 & 149 & 68 & & \\
\hline & Total & 96 & 43.8 & 123 & 56.2 & 219 & 100 & & \\
\hline
\end{tabular}


Table-3: Summary of Significant test parameters parenting, child development preschool age

\begin{tabular}{|c|c|c|c|c|c|}
\hline \multirow[t]{2}{*}{ Variable } & \multirow[t]{2}{*}{$\mathbf{B}$} & \multirow{2}{*}{$\begin{array}{r}\text { Sig } \\
\text { (P) }\end{array}$} & \multirow{2}{*}{$\begin{array}{c}\operatorname{Exp}(\mathrm{B}) \\
\text { (OR) }\end{array}$} & \multicolumn{2}{|c|}{ 95\% C.I.for EXP (B) } \\
\hline & & & & Lower & Upper \\
\hline Practice Giving food & -2.026 & 0.013 & 0.132 & 0.026 & 0.657 \\
\hline Practice hiegene and health & 2,683 & 0,000 & 14,636 & 4,433 & 48,323 \\
\hline Practice love dear & 3,555 & 0,000 & 35,005 & 9,783 & 125,261 \\
\hline Stimulation practices & 0.019 & 0.976 & 1.019 & 0.298 & 3.482 \\
\hline
\end{tabular}

\section{DISCUSSION}

The Effect of Parenting on the Development of Preschoolers. The need for foster care can be said to be the primary need for toddlers, if this need cannot be met, it will have a negative impact on the child's growth and development. One of the negative impacts for children whose nutritional needs are not fulfilled will experience failure of physical growth, decreased IQ, decreased productivity, decreased resistance to disease infections, and an increased risk of contracting diseases and experiencing higher mortality [10]. Another impact if this need is not fulfilled will lead to suboptimal brain development [11].

The results showed that the feeding practice was mostly $(40.2 \%)$ lacking, the feeding practice $(59.8 \%)$ was good. From $59.3 \%$ of good feeding practices, the results of observations using DDST were obtained, namely $39.3 \%$ of children's development there was no delay, analysis Chi square showed that the practice of feeding had a $p$-value $<0.05$ ( $p$-value) which this means that there is a significant effect of feeding practices on child development.

The results of this study supported by Lester, et al. [12] with the results of research on get that there is a relationship between infant feeding practices with nutritional status of children in sub-district village Tembalang mateseh Semarang results showed that the practice of health hiegene and most $(40.2 \%)$ less, the parenting pattern of feeding practice $(58.4 \%)$ is good, from $58.4 \%$ of the practice of giving adequate food, the DDST observation results are obtained, namely $48.4 \%$, there is no delay analysis Chi square shows that the practice of giving food has a p-value $<0.05$ ( $p$-value), which means that there is a significant influence on hygiene and health parenting practices on children's development.

The results of this study were supported by Siti Aisah [13], with the results of her research which showed a relationship between personal hygiene and environmental sanitation and the incidence of stunting in Wukirsari village, Cangkringan district.

The results showed that the practice of giving compassion was mostly (48.9\%) lacking, the practice of giving affection $(51.1 \%$ ) was good. From $51.1 \%$ of good practice of affection, the DDST observation results were $44.7 \%$, there was no delay analysis $C h i$ square shows that the practice of affection has a $p$-value
$<0.05$ ( $p$-value $=0.000)$, which means that there is a significant relationship between the practice of affection and child development with a value of RP = 22.960, meaning that good practice of giving love has a chance. 22,960 times there was no delay in child development.

The results of this study are supported by Latifah et al. [14] with the results of the study showing that children who are safely attached to their mothers as caregivers have better cognitive development scores compared to children who are not safely attached to their mothers.

The results showed that the stimulation practice was mostly (32\%) lacking and the stimulation practice $(68 \%)$ was good. From $68 \%$ of good stimulatory practices, the observation results using DDST were obtained, namely $42.9 \%$ of children's development there was no delay, analysis Chi square showed that the sharpening pattern had a $p$-value $<0.05$ ( $p$-value) which meant that there was a significant effect. Hone patterns to fine motor development of children.

The results of this study were supported by [15] with the results of her research which showed that there was a significant relationship between stimulation of child development and development of children aged 13 years in Sedayu sub-district.

Physical nutritional status, namely weight growth can be influenced by children's food intake and health conditions are influenced by the care carried out by parents, including the behavior of parents in providing food to children [16].

According to the assumptions of researchers, to get a parenting style that is in accordance with children's development requires a healthy lifestyle through good feeding practices, compassion practices, stimulation practices, planting clean and regular living habits and providing medication and care so that the child is always in a healthy condition. Practice hiegen and health affect the health status of children under five and will ultimately affect the nutritional status of children and will ultimately affect the child's development

\section{Conclusion}

There was a significant effect of feeding practices, practice hyegen and health, the practice of 
compassion, and practice stimuluasi against childhood development preschool.

\section{REFERENCES}

1. Maslakah, N., \& Setiyaningrum, Z. (2017). Pengaruh Pendidikan Media Flashcard Terhadap Pengetahuan Anak Tentang Pedoman Umum Gizi Seimbang Di Sd Muhammadiyah 21 Baluwarti Surakarta. Jurnal Kesehatan, 10(1), 9-16.

2. Smith, T. J., Temin, S., Alesi, E. R., Abernethy, A. P., Balboni, T. A., Basch, E. M., Ferrell, B. R., Loscalzo, M., Meier, D. E., \& Paice, J. A. (2012). American Society of Clinical Oncology provisional clinical opinion: the integration of palliative care into standard oncology care. Journal of Clinical Oncology, 30(8), 880-887.

3. Hidayat, A. A. A. (2008). Asuhan Neonatus Bayi dan Balita.

4. WHO, U. (2012). UNFPA, The World Bank. Trends in maternal mortality: 1990 to 2010. WHO, UNICEF. UNFPA, and The World Bank Estimates.

5. Fitri, R. D. (2016). Hubungan karakteristik ibu dengan kemampuan menstimulasi perkembangan motorik kasar anak usia 0-12 bulan di Desa Bukit Meusara Kota Jantho Kabupaten Aceh Besar. Health Science Growth (HSG) Journal, 1(1).

6. Hidayah, W., \& CK, A. (2016). Hubungan Antara Tingkat Pendidikan Ibu Dengan Perkembangan Balita Usia 3-5 Tahun (Suatu Studi Dikelurahan Kadipaten Kecamatan Bojonegoro Kabupaten Bojonegoro Tahun 2014) Relationship Between Education Level Mother with Toddler Development Age 3-5 Years. Asuhan Kesehatan: Jurnal Ilmiah Ilmu Kebidanan Dan Keperawatan, $7(2)$.
7. Unicef. (2012). The state of the world's children 2012: children in an urban world. eSocialSciences.

8. Septiari, B. B. (2012). Infeksi nosokomial. Yogyakarta: Nuha Medika, 49-89.

9. Timmreck, T. (2005). Epidemiologi suatu pengantar. EGC.

10. Rahmiati, R. (2011). Hubungan Pemberian ASI Ekslusif dan Penyakit Infeksi Terhadap Status Gizi Bayi Umur 7 Bulan di Wilayah Kerha Puskesmas Wawondula kecamatan Towuti Kabupaten Luwu Timur Tahun 2011. Universitas Islam Negeri Alauddin Makassar.

11. Silangit, A. D. (2020). Hubungan pengetahuan dan sikap ibu menikah dini terhadap pola asuh anak balita di dusun ii ampera selatan desa sekip kecamatan lubuk pakam kabupaten deli serdang. Jurnal Mutiara Kebidanan, 6(2), 84-91.

12. Lester, M. (2013). Practice Makes Perfect English Articles and Determiners Up Close. McGraw Hill Professional.

13. Sulistiyowati, T., \& Siswantara, P. (2014). Perilaku Ibu Bekerja dalam Memberikan ASI Eksklusif di Kelurahan Japanan Wilayah Kerja Puskesmas Kemlagi Mojokerto. Jurnal Promkes, 2(1), 89-100.

14. Latifah, D. (2016). Sundanese traditional tone sensitivity-based audiation model of salendro musical scale. Harmonia: Journal of Arts Research and Education, 16(2), 172-181.

15. Hati, F. S., \& Lestari, P. (2016). Pengaruh pemberian stimulasi pada perkembangan anak usia 12-36 bulan di Kecamatan Sedayu, Bantul. Jurnal Ners Dan Kebidanan Indonesia, 4(1), 44-48.

16. Organization, W. H., \& UNICEF. (2013). Progress on sanitation and drinking-water. World Health Organization. 